\title{
STUDENTS' PERCEPTION OF LEARNING ENVIRONMENT USING DUNDEE READY EDUCATION ENVIRONMENT MEASURE (DREEM) INVENTORY
}

\author{
Khola Noreen ${ }^{1}$, Kausar Aftab Khan², Risat Ali Nehra ${ }^{3}$
}

\author{
${ }^{1}$ Assistant Professor, Department of Community Health Sciences, Gujranwala Medical College Gujranwala, \\ Pakistan \\ ${ }^{2}$ Assistant Professor, Department of Community Health Sciences, Gujranwala Medical College Gujranwala, \\ Pakistan \\ ${ }^{3}$ Assistant Professor, Anatomy Department, Pakistan Red Crescent Medical \& Dental College Dina Nath, Pakistan \\ Correspondence: Khola Noreen, Email:dr_khaula@yahoo.com
}

\begin{abstract}
Background: Educational Environment is defined as everything that take place in class room, department, college or university and is fundamental in achievement of students' academic success. Understanding the medical student's perception about the education environment has great impact in evaluating deficiencies in exiting medical curriculum, to make comparison between different groups and to make necessary changes accordingly. The objective of our study was to evaluate the perception of under graduate medical students about their learning environment.

Methods: We conducted this cross-sectional study on 131 undergraduate medical students. DREEM Inventory was used to collect the data. DREEM is validated tool and universally used as diagnostic inventory to assess the quality of education environment. Data was collected after taking informed written consent.

Results: Students' perceptions of learning, students' perceptions of teachers, students' academic self-perceptions, students' perceptions of atmosphere, students' social self-perceptions and total DREEM score were 25.4/48, $23.3 / 44,17.3 / 32,27 / 48,14.3 / 28$ and $107.5 / 200$, respectively. Out of total 50 item, 11 items scored less than 2 which indicate the area of significant problem and these issues need to be addressed on urgent basis.

Conclusion: Over all students assessed education environment as average. There is a need for improvement in all five domains of students' perception.
\end{abstract}

Keywords: Medical students, DUNDEE, educational environment, students' perception

\section{Introduction}

Educational Environment is defined as everything that take place in class room, department, college or university and is fundamental in achievement of success of under graduate medical education(1,2). There is evidence that educational environment experienced by medical students has great impact not only on their academic performance but also on overall well being and satisfaction (3).

Perception of education environment has direct influence on motivation, contentment and crucial for effective learning of medical student .Since educational environment is measurable, evaluation of education environment is important to bring about the necessary changes and improvement where required (4).

Understanding the medical student's perception about the education environment has great impact in evaluating deficiencies in exiting medical curriculum, to make comparison between different groups and to make necessary changes accordingly. It can play essential role in planning and implementing the comprehensive curriculum (5).Learning experience at medical college has great influence on student's lifelong knowledge and practice (6).

Several instruments are being utilized to assess the medical students' perception about learning environment in medical institutes. The Dundee Ready Education Environment Measure (DREEM) is validated international educational tool used widely to assess the medical students perception about their education environment $(7,8)$.

DREEM was developed in 1997 using Delphi method for assessing the educational environment throughout the world ,which was based on Postgraduate Hospital Educational Environment Measure (PHEEM), Surgical Theatre Educational Environment Measure (STEEM), the Medical Educational Environment Measure (MEEM), and Anaesthetic Theatre Educational 
Environment Measure (ATEEM)(9).

Being the part of teaching faculty we are constantly working on devising the ways and adopt new teaching and learning strategies to improve existing medical education system of country. There is limited published data in this regard and very little information is available from our part of world. This has led us to explore the students perception about the education environment of our medical institute. This would definitely help the stake holders and policy makers to identify the weak areas and implement the necessary changes as required.

\section{Methodology}

DREEM inventory was used to gather information about education environment. It has been validated and used as universal diagnostic inventory to assess the education environment at different institution(10).

The DREEM Inventory is close ended questionnaire consisting of 50 statements and divided into 5 subscales:

Students' perception of learning (12 items);

Students' perceptions of teachers (11 items);

Students' academic self-perceptions (8 items);

Students' perceptions of atmosphere (12 items) and

Students' social self-perceptions (7 items).

Each statement is scored on five point likert scale consisting of "Strongly agree" (4), "Agree" (3) "Unsure" (2) "Disagree" (1) and "Strongly disagree" (0) (11).

Reverse coding is required for item number $4,8,9,17$, $25,35,39,48$ and 50 .The results of DREEM can be analyzed at individual level, sub scales and over all DREEM Score. Raw scores of each participant are analyzed and summed up at individual level then mean scores are analysed to obtain sub scale summary. Evaluation at individual level enable us to identify specific area of strengths and weakness. higher the score better is the evaluation. Highest score is 200, which represents the ideal education environment(12).

This cross sectional survey was conducted from April 2017- September 2017, at Gujranwala medical College, Gujranwala. Data was collected from 131 under graduate medical students. After obtaining ethical approval, DREEM questionnaire was distributed to all students willing to participate in study. Before data collection, all participants were given brief description of aim of study and any ambiguity was addressed specially with regards to their voluntary participation and anonymity .Questionnaire was distributed at the end of lecture by senior faculty member. Students were requested to complete the questionnaire within 20 minutes and returned it to concerned authority. Students were instructed to avoid discussion in order to avoid bias and timely completion of questionnaire. If they complete all sections before the designated time they were allowed to leave the Lecture Hall. Separate consent form was filled before data collection. Data were analysed using SPSS version 23. Descriptive analysis was done by calculating mean $+S D$. Mean scores were calculated at individual item, domains, sub scales and scales of DREEM inventory. The Practical Guide described by McAleer and Roff13 for interpreting the overall and subscale scores, and the number of items in each subscale is given in Table 1.

Table 1: Guideline to interpret the overall and subscale DREEM scores (13)

\begin{tabular}{|c|c|}
\hline Total and individual scores & - \\
\hline \multicolumn{2}{|l|}{ Total score } \\
\hline $0-50$ & Very poor \\
\hline $51-100$ & Significant problem \\
\hline $101-150$ & More positive than negative \\
\hline $151-200$ & Excellent \\
\hline \multicolumn{2}{|l|}{ Individual item } \\
\hline . & Problem areas \\
\hline $2-3$ & Could be enhanced \\
\hline$\ldots$ & Real positive points \\
\hline \multicolumn{2}{|l|}{ Subscales } \\
\hline \multicolumn{2}{|l|}{ SPL } \\
\hline $0-12$ & Very poor \\
\hline $12-25$ & Negatively viewed teaching \\
\hline $25-37$ & A more positive perception \\
\hline $37-48$ & Teaching highly regarded \\
\hline \multicolumn{2}{|r|}{ 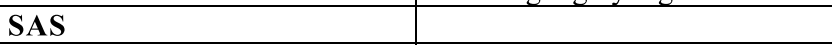 } \\
\hline $0-8$ & Feelings of total failure \\
\hline $9-16$ & Many negative aspects \\
\hline $17-24$ & Feeling more on the positive side \\
\hline $25-32$ & Confident \\
\hline \multicolumn{2}{|l|}{ SSS } \\
\hline $0-7$ & Miserable \\
\hline $8-14$ & Not a nice place \\
\hline $15-21$ & Not too bad \\
\hline $22-28$ & Very good socially \\
\hline \multicolumn{2}{|l|}{ SPT } \\
\hline $0-11$ & Very poor \\
\hline $12-22$ & Negatively viewed teaching \\
\hline $23-33$ & A more positive perception \\
\hline $34-44$ & Teaching highly regarded \\
\hline \multicolumn{2}{|l|}{ SPA } \\
\hline $0-12$ & Very poor environment \\
\hline $13-24$ & Many issues need changing \\
\hline $25-36$ & A more positive attitude \\
\hline $37-48$ & A good overall feeling \\
\hline
\end{tabular}

\section{Results}

Table 2 shows mean score of each item across different domains. Domain regarding Student perception of learning (SPL) contains 12 items, its score ranged between 1.45 to 2.55 . Item number 25 and 48 received the lowest score. Score of these two items is less than 2 and it indicates problem area. Score of Next Domain Student Perception of Teacher (SPT) ranged between 3.12 to 1.54 .Item No 6,8 and 9 score less than 2 which indicate the problem area .

Next domain of Student Academic Self Perception (SASP) ranged between 2.76 to 1.41 . None of item scored more than 3 . Item 5, 26 and 27 scored minimum and suggestive of area for improvement. Domain of Student perception of atmosphere (SPA) ranged between 2.41 to 1.52 with only one item "The enjoyment outweighs the stress of studying medicine" score less than 2. Last domain Student social self perception (SSSP) ranged between 2.14 to 1.67 and item number 4 
and 14 shoed the area for improvement. Item in which score is less than 2 were highlighted. Details of all 50 items are shown in Table 2.

Table 2: Mean (SD) DREEM item scores according to domains

\begin{tabular}{|c|c|c|}
\hline Domain & Statement & Mean(SD) \\
\hline \multirow[t]{12}{*}{ SPL } & 1. I am encouraged to participate in teaching sessions & $2.55(0.69)$ \\
\hline & 7. The teaching is often stimulating & $2.12(0.75)$ \\
\hline & 13. The teaching is registrar centered & $2.52(.92)$ \\
\hline & 16. The teaching helps to develop my confidence & $2.11(0.83)$ \\
\hline & 20. The teaching is well focused & $2.11(0.70)$ \\
\hline & 21. The teaching helps to develop my confidence & $2.17(0.88)$ \\
\hline & 24. The teaching time is put to good use & $2.41(0.83)$ \\
\hline & 25. The teaching overemphasizes factual learning & $1.45(0.84)$ \\
\hline & 38. I am clear about the learning objectives of the course & $2.17(0.84)$ \\
\hline & 44. The teaching encourages me to be an active learner & $2.39(0.84)$ \\
\hline & 47. Long term learning is emphasized over short term learning & $2.12(1.09)$ \\
\hline & 48. The teaching is too teacher centered & $1.33(1.12)$ \\
\hline \multirow[t]{11}{*}{ SPT } & 2. The course organizers are knowledgeable & $3.12(0.59)$ \\
\hline & $\begin{array}{l}\text { 6. The course organizers espouse a patient centered } \\
\text { approach to consulting }\end{array}$ & $1.76(1.12)$ \\
\hline & 8. The course organizers ridicule their registrars & $1.86(1.05)$ \\
\hline & 9. The course organizers are authoritarian & $1.54(0.98)$ \\
\hline & $\begin{array}{l}\text { 18. The course organizers appear to have effective } \\
\text { communication skills with patients }\end{array}$ & $2.13(1.21)$ \\
\hline & $\begin{array}{l}29 . \text { The course organizers are good at providing feedback to } \\
\text { registrars }\end{array}$ & $2.41(0.95)$ \\
\hline & 32. The course organizers provide constructive criticism here & $2.01(1.11)$ \\
\hline & 37. The course organizers give clear examples & $2.75(0.88)$ \\
\hline & 39. The course organizers get angry in teaching sessions & $2.16(2.08)$ \\
\hline & $\begin{array}{l}\text { 40. The course organizers are well prepared for their teaching } \\
\text { sessions }\end{array}$ & $2.98(1.51)$ \\
\hline & 49. The registrars irritate the course organizers & $2.12(1.09)$ \\
\hline \multirow[t]{8}{*}{ SASP } & $\begin{array}{l}\text { 5. Learning strategies which worked for me before continue } \\
\text { to work for me now }\end{array}$ & $1.72(1.11)$ \\
\hline & 10. I am confident about passing this year & $2.75(2.21)$ \\
\hline & 22. I feel I am being well prepared for my profession & $2.45(0.94)$ \\
\hline & $\begin{array}{l}\text { 26. Last years work has been a good preparation for this } \\
\text { years work }\end{array}$ & $1.79(1.17)$ \\
\hline & 27. I am able to memorize all I need & $1.41(1.09)$ \\
\hline & 31. I have learned a lot about empathy in my profession & $2.31(1.10)$ \\
\hline & 41. My problem solving skills are being well developed here & $2.13(0.97)$ \\
\hline & $\begin{array}{l}\text { 45. Much of what I have to learn seems relevant to a career in } \\
\text { healthcare }\end{array}$ & $2.76(0.79)$ \\
\hline \multirow[t]{12}{*}{ SPA } & 11. The atmosphere is relaxed during consultation teaching & $2.16(1.08)$ \\
\hline & 12. The course is well time tabled & $2.28(1.16)$ \\
\hline & 17. Cheating is a problem in this course & $2.38(1.19)$ \\
\hline & 23. The atmosphere is relaxed during lectures & $2.12(1.29)$ \\
\hline & $\begin{array}{l}\text { 30. There are opportunities for me to develop interpersonal } \\
\text { skills }\end{array}$ & $2.41(0.90)$ \\
\hline & 33. I feel comfortable in teaching sessions socially & $2.41(0.85)$ \\
\hline & 34. The atmosphere is relaxed during seminars/tutorials & $2.33(1.08)$ \\
\hline & 35. I find the experience disappointing & $2.28(1.181)$ \\
\hline & 36. I am able to concentrate well & $2.12(0.93)$ \\
\hline & $\begin{array}{l}\text { 42. The enjoyment outweighs the stress of studying } \\
\text { medicine }\end{array}$ & $1.52(1.21)$ \\
\hline & 43. The atmosphere motivated me as a learner & $2.31(1.11)$ \\
\hline & 50. I feel able to ask the questions I want & $2.24(1.43)$ \\
\hline \multirow[t]{7}{*}{ SSSP } & $\begin{array}{l}\text { 3. There is a good support system for registrars who get } \\
\text { stressed }\end{array}$ & $2.09(1.12)$ \\
\hline & 4. I am too tired to enjoy this course & $1.67(1.12)$ \\
\hline & 14. I am rarely bored on this course & $1.75(1.21)$ \\
\hline & 15. I have good friends in this course & $2.11(0.87)$ \\
\hline & 19. My social life is good & $2.31(1.12)$ \\
\hline & 28. I seldom feel lonely & $2.32(1.18)$ \\
\hline & 46. My accommodation is pleasant & $2.14(1.12)$ \\
\hline
\end{tabular}

Table 3 shows the overall DREEM score and mean score across different domains. The overall score was $107.5 / 200$ which indicates more positive than negative. The total score of domain 1 D1 was 25.4/48, for D2 IT WAS 23.3/44,D3 was found to be 17.3/32,D4 WAS 27/ 48 and score of D5 was calculated to be 14.3/28 .
Table 3: Total results of DREEM Domains $(\mathrm{N}=131)$

\begin{tabular}{|l|l|l|l|l|}
\hline Domain DREEM & $\begin{array}{l}\text { Number of } \\
\text { questions }\end{array}$ & $\begin{array}{l}\text { Maximum } \\
\text { DREEM score }\end{array}$ & Mean & SD \\
\hline Domain 1. Learning & 12 & 48 & 25.45 & 4.19 \\
\hline Domain 2. Teachers & 11 & 44 & 23.33 & 5.12 \\
\hline Domain 3. Academics & 8 & 32 & 17.32 & 4.78 \\
\hline Domain 4. Atmosphere & 12 & 48 & 27.01 & 6.12 \\
\hline Domain 5. Social Life & 7 & 28 & 14.39 & 4.13 \\
\hline Total DREEM score & 50 & 200 & 107.5 & 24.34 \\
\hline
\end{tabular}

\section{Discussion}

Main purpose of medical education is to design the curriculum that enables medical students to become successful healer in future. Education environment is most important determining factor in success full implementation of curriculum at medical institutes. In our study we aim to evaluate the perception of education environment at our institute. The overall DREEM score was $107.5 / 200$ which was within range of 101-150 which is suggestive of more positives as compared to negative perception. (13)

Over all DREEM score $107.5 / 200$ is lower as compared to previous study conducted by Rehana et al (14) but comparable to other studies from India 107/200, 114/200 (15-16).Study of Malaysia (17) and Nepal (18) reported mean score $125.3 / 200$ and 129/200 respectively. DREEM scores from study conducted at Sri Lanka $108 / 200$ and Trinidad are 109/200 are comparable to our study $(19,20)$. Lowest score 89/200 has been reported from Saudi Arabia at the College of Medicine at King Saud University followed by $97 / 200$ reported by a study of the Canadian Memorial Chiropractic College $(21,22)$.

On analysis of individual domains of education environment, Domain 1 Students perception about learning (SPL) score was calculated to be 25.45/48 which is at the borderline of "more positive perception". Two DREEM items scored less than 2 which indicates problem area. These items were The teaching overemphasizes factual learning (1.45) and teaching is too teacher centered (1.33). In our institute Lectures are considered to be main mode of teaching strategy which is mainly teacher centered and based on transfer of factual knowledge. According to adult learning theory teaching should be based on active learning principle in which learner actively participates in learning process (23). There is more emphasis on developing students' skill rather than just transfer of factual knowledge (24). Several researches have proved that active learning techniques like small group discussion, case based learning, problem based learning are more effective mode of teaching (25).

Regarding Domain 2 Students Perception About Teachers (SPT) again response (23.33/44) is at border line of "more positive perception". Three DREEM Items "The course organizers espouse a patient centered approach to consulting", "The course organizers ridicule their registrars" and The course organizers are authoritarian were less than 2 ,indicating the problem areas. These three points again indicate the didactive 
mode of teaching and strongly suggests that teaching is mostly teacher centered. According to principle of adult learning ,teaching should be learner centered and role of teacher should be changed to facilitator instead of knowledge transmitter(26). Teachers should not ridicule their students instead they should actively engage them in learning and they should reflect whatever they learn(27).

Result of Domain 3 Students academic self-perception (SASP) were again at the border line of more positive and negative i.e. 17.3 /32 problem areas were "Learning strategies which worked for me before continue to work for me now", "Last year's work has been a good preparation for this year work", "I am able to memorize all I need". These points again indicate that there is dire need to change the teaching learning strategies. More over in our institute integrated curriculum is still not implemented. Students are still taught in traditional manner in which basic and clinical sciences has been compartmentalized separately. This is why reason that students are not able to integrate their previous knowledge in current practice. The concept of integrated curriculum is becoming popular worldwide and the aim of integration is to break the barrier between clinical and basic sciences and allow them to integrate their previous knowledge into their current practice (28). Integration facilitates the retention of previous knowledge acquired and development of new skills through repetition and practical application(29) .

Score of Domain Students perception of atmosphere (SPA) 27/48 indicates "A more positive attitude", only problem was "The enjoyment outweighs the stress of studying medicine". Evidence has supported the fact that stress during medical education can deteriorate the overall performance of medical students. Stress can be related to academics and environment(30) Currently in our institute there is no student support system . There is dire need to establish Counseling cells and student support system so that students will be able to perform to best of their capabilities(31).

Students' Social Self-Perceptions (SSSP) score was $14 / 28$. Two item which score less than 2 indicate that students were stressed and really bored of their course. These findings also strongly suggestive of remedial action in curriculum design and teaching strategies.

Our study has highlighted the weak areas and provided the base line data for curriculum committee and other stake holders to implement necessary changes. Target strategies need to formulate to address the particular deficiencies and to strengthen the education environment of our institute. There is dire need of implementation of integrated curriculum. Faculty development programs and training courses should be initiated. There is need to shift the teaching learning strategy from teacher centered to student centered approach. Teaching strategy should be changed from large class lecture to small group problem based learning that will help to develop higher order skills and enable them to integrate the acquired knowledge into clinical practice. There is need to restructure clinical rotation program and development of student support system. Our study has provided the base line data for further comparative study after implementing necessary changes in order to access the improvement.

\section{Conclusion}

Over all students assessed education environment as average. There is a need for improvement in all five domains of students' perception.

\section{References}

1. AMEE Medical Education Guide No. 23 (Part 2): Curriculum, environment, climate, quality and change in medical education - a unifying perspective.Genn JM Med Teach. 2001; 23(5):445-54

2. Patil, A. A., \& Chaudhari, V. L. (2016). Students' perception of the educational environment in medical college: a study based on DREEM questionnaire. Korean Journal of Medical Education, 28(3), 281-288. http://doi.org/ 10.3946/kjme.2016.32

3. Susan Miles, Louise Swift \& Sam J. Leinster (2012) The Dund ee Ready Education Environment Measure (DREEM): A review of its adoption and use, Medical Teacher, 34:9, e620e634, DOI: 10.3109/0142159X.2012.668625

4. Roff S, McAleer, Ifere OS, Bhattacharya S: A global diagnostic tool for measuring educational environment: comparing Nigeria and Nepal. Med Teach. 2001, 23 (4): 378-382. 10.1080/01421590120043080.

5. Genn JM, Harden RM. What is medical education here really like? Suggestions for action research studies of climates of medical education environments. Med Teach 1986; 8(2)111-124

6. Schönrock-Adema, J., Bouwkamp-Timmer, T., van Hell, E. A., \& Cohen-Schotanus, J. (2012). Key elements in assessing the educational environment: where is the theory? Advances in Health Sciences Education, 17(5), 727-742. http://doi.org/10.1007/s10459-011-9346-8

7. The Dundee Ready Educational Environment Measure (DREEM)--a generic instrument for measuring students' perceptions of undergraduate health professions curricula. Roff S Med Teach. 2005 Jun; 27(4):322-5.

8. S. Roff, S. McAleer, R. M. Harden et al., "Development and validation of the Dundee Ready Education Environment Measure (DREEM)," Medical Teacher, vol. 19, no. 4, pp. 295-299, 1997.

9. S. Miles, L. Swift, and S. J. Leinster, "The Dundee Ready Education Environment Measure (DREEM): a review of its adoption and use," Medical Teacher, vol. 34, no. 9, pp. 620634, 2012. 
10. Roff S, McAleer S, Harden R, Al-Qahtani M, Ahmed A, Deza H, Groenen G, Primparyon P: Development and validation of the Dundee Ready Education Environment Measure (DREEM). Med Teach. 1997, 19: 295-299. 10.3109/01421599709034208

11. S. McAleer and S. Roff, "A practical guide to using the Dundee Ready Education Environment Measure (DREEM)," AMEE Medical Education Guide, vol. 23, pp. 29-33, 2001.

12. S. Miles, L. Swift, and S. J. Leinster, "The Dundee Ready Education Environment Measure (DREEM): a review of its adoption and use," Medical Teacher, vol. 34, no. 9, pp. 620634, 2012

13. S. McAleer and S. Roff, "A practical guide to using the Dundee Ready Education Environment Measure (DREEM)," AMEE Medical Education Guide, vol. 23, pp. 29-33, 2001.

14. RehmanR, GhiasK, Fatima SS,Hussain M, Alam F. Students'perception of educational environment at Aga Khan University Medical College, Karachi, Pakistan. Pak J Med Sci 2016; 32: 720-4.Khan University Medical College, Karachi, Pakistan. Pak J Med Sci 2016; 32: 7204.

15. Mayya S, Roff S. Students' perceptions of educational environment: a comparison of academic achievers and under-achievers at Kasturba medical college, India. Educ Health (Abingdon). 2004;17:280-91.

16. Abraham R, Ramnarayan K, Vinod P, Torke S. Students' perceptions of learning environment in an Indian medical school. BMC Med Educ. 2008;8:20.

17. Al-Naggar RA, Abdulghani $M$, et al. The Malaysia DREEM: perceptions of medical students about the learning environment in a medical school in Malaysia. Adv Med Educ Pract. 2014;5:177-8

18.. Roff S, McAleer S, Ifere OS, Bhattacharya S. A global diagnostic tool for measuring educational environment: comparing Nigeria and Nepal. Med Teach. 2001;23(4):378-82.

19. Jiffry MT, McAleer S, Fernando S, Marasinghe RB. Using the DREEM questionnaire to gather baseline information on an evolving medical school in Sri Lanka. Med Teach. 2005;27(4):348-5

20. Bassaw B, Roff S, McAleer S, et al. Students' perspectives on the educational environment, Faculty of Medical Sciences. Trinidad Med Teach. 2003;25(5):522-6.

21. Ayed IH, Sheik SA. Assessment of the educational environment at the College of Medicine of King Saud University, Riyadh. East
Mediterr Health J. 2008;14(4):953-9

22. Audin K, Davy J, Barkham M. University quality of life and learning (UNIQoLL): an approach to student well-being, satisfaction and institutional change. J Furth High Educ. 2003;27(4):365-82

23. Barkl ey EF. 1st ed. San Franci sco (CA): JosseyBass? 2010. St dent engagement techniques. Ahandbook for college faculty .

24. Hoel lwart h C, Moel t er MJ. The implications of a robust curriculum in introductory mechanics. Am Jn Phys. 2011? 79: 540-5

25. Hake RR. Interactive engagement versus traditional methods: A sixthousandstudent survey of mechanics test data for introductory physics course. Am J Phys. 1998? 66: 64-74

26. Harden RM, Lai dl aw SL. Elsevier, Churchill Livingstone? 2012. Essential skills for a medical teacher. An introduction to teaching and I earn ng in medicine

27. Barkl ey EF. 1st ed. San Franci sco (CA): JosseyBass? 2010. St udent engagement $t$ echni ques. Ahandbook for col l ege facul ty

28. Brauer DG, Ferguson KJ. The integrated curriculum in medical education: AMEE Guide No. 96. Med Teach. 2015;37(4):312-2

29. Schapiro R et al. Integrative cases for preclinical medical students: connecting clinical, basic science, and public health approaches. Am J Prev Med. 2011;41(4 Suppl 3):S187-92.

30. Anuradha, R., Dutta, R., Raja, J. D., Sivaprakasam, P., \& Patil, A. B. (2017). Stress and Stressors among Medical Undergraduate Students: A Cross-sectional Study in a Private Medical College in Tamil Nadu. Indian Journal of Community Medicine?: Official Publication of Indian Association of Preventive \& Social Medicine, 42(4), 222-225. http://doi.org/ 10.4103/ijcm.IJCM_287_16

31. Satheesh BC, Prithviraj R, Prakasam PS. A study of perceived stress among undergraduate medical students of a private medical college in Tamil Nadu. Int J Sci Res. 2015;4:994-7. 